\title{
Rock glaciers represent hidden water stores in the Himalaya
}

D. B. Jones ${ }^{1 *}$, K. Anderson ${ }^{2}$, S. Shannon ${ }^{3}$, R. A. Betts ${ }^{4,5}$ and S. Harrison ${ }^{1}$

${ }^{1}$ College of Life and Environmental Sciences, University of Exeter, Penryn Campus, Penryn, Cornwall, TR10 9EZ, UK.

2 Environment and Sustainability Institute, University of Exeter, Penryn Campus, Penryn, Cornwall, TR10 9EZ, UK.

3 Bristol Glaciology Centre, Department of Geographical Science, University Road, University of Bristol, BS8 1SS, UK

${ }^{4}$ College of Life and Environmental Sciences, University of Exeter, Streatham Campus, Exeter, EX4 4QE, UK.

5 Met Office, FitzRoy Road, Exeter, Devon, EX1 3PB, UK

K. Anderson: Email: Karen.Anderson@exeter.ac.uk

S. Shannon Email: Sarah.shannon@bristol.ac.uk

R. A. Betts: Email: R.A.Betts@exeter.ac.uk

S. Harrison: Email: Stephan.Harrison@exeter.ac.uk

Corresponding Author (*): Email: dj281@exeter.ac.uk 


\section{Abstract}

2 In High Mountain Asia (HMA), ongoing glacier retreat affects human and ecological systems

3 through reduced water availability. Rock glaciers are climatically more resilient than glaciers and

4 likely contain potentially valuable water volume equivalents (WVEQ). In HMA knowledge of rock

5 glaciers is extremely sparse and here we present the first systematic assessment of rock glaciers

6 for the Himalaya, which encompass $\sim 25,000$ landforms with an estimated areal coverage of 3,747

$7 \quad \mathrm{~km}^{2}$. We estimate the WVEQ of Himalayan rock glaciers to be $51.80 \pm 10.36 \mathrm{~km}^{3}$ (41-62 trillion

8 litres). Their comparative importance vs glaciers (rock glacier: glacier WVEQ ratio) in the

9 Himalaya was 1:24, ranging between 1:42 and 1:17 in the East and Central Himalaya, respectfully.

10 We show that Himalayan rock glaciers constitute hydrologically valuable long-term water stores.

11 In the context of ongoing glacier recession and mass loss, their relative hydrological value in

12 mountain regions will likely increase and deserves greater study.

\section{Main}

15 In High Mountain Asia (HMA), which comprises the Tibetan Plateau and its surrounding mountain ranges (including the Himalaya, Karakoram, Tien Shan, and Pamir), the cryosphere forms natural water towers that are integral for ecosystem services provision, and for supplying multiple societal needs to $\sim 800$ million people living in the mountains and surrounding lowlands ${ }^{1}$. However, considerable continued glacier mass loss is projected throughout the twenty-first century ${ }^{2-4}$. Under high-end climate scenarios, warming that exceeds $2{ }^{\circ} \mathrm{C}$ global average during the twenty-first century (RCP8.5), relative to the pre-industrial period will result in projected HMA glacier volume loss of $\sim 95 \%$ by 2100 , relative to the present-day. Volume losses are driven by an average temperature change of $+5.9^{\circ} \mathrm{C}$ and $+20.9 \%$ rise in average precipitation, the latter increasingly of rain (Fig. 1). Indeed, reductions in snow water equivalent have been reported for a number of catchments in HMA, particularly during spring and summer ${ }^{5}$. For the RCP4.5 scenario, most basins fed by HMA glaciers are projected to reach peak water by 2050; $2045 \pm 17$ years (Indus), $2044 \pm 21$ years (Ganges) and $2049 \pm 18$ years (Brahmaputra), for example ${ }^{6}$. 

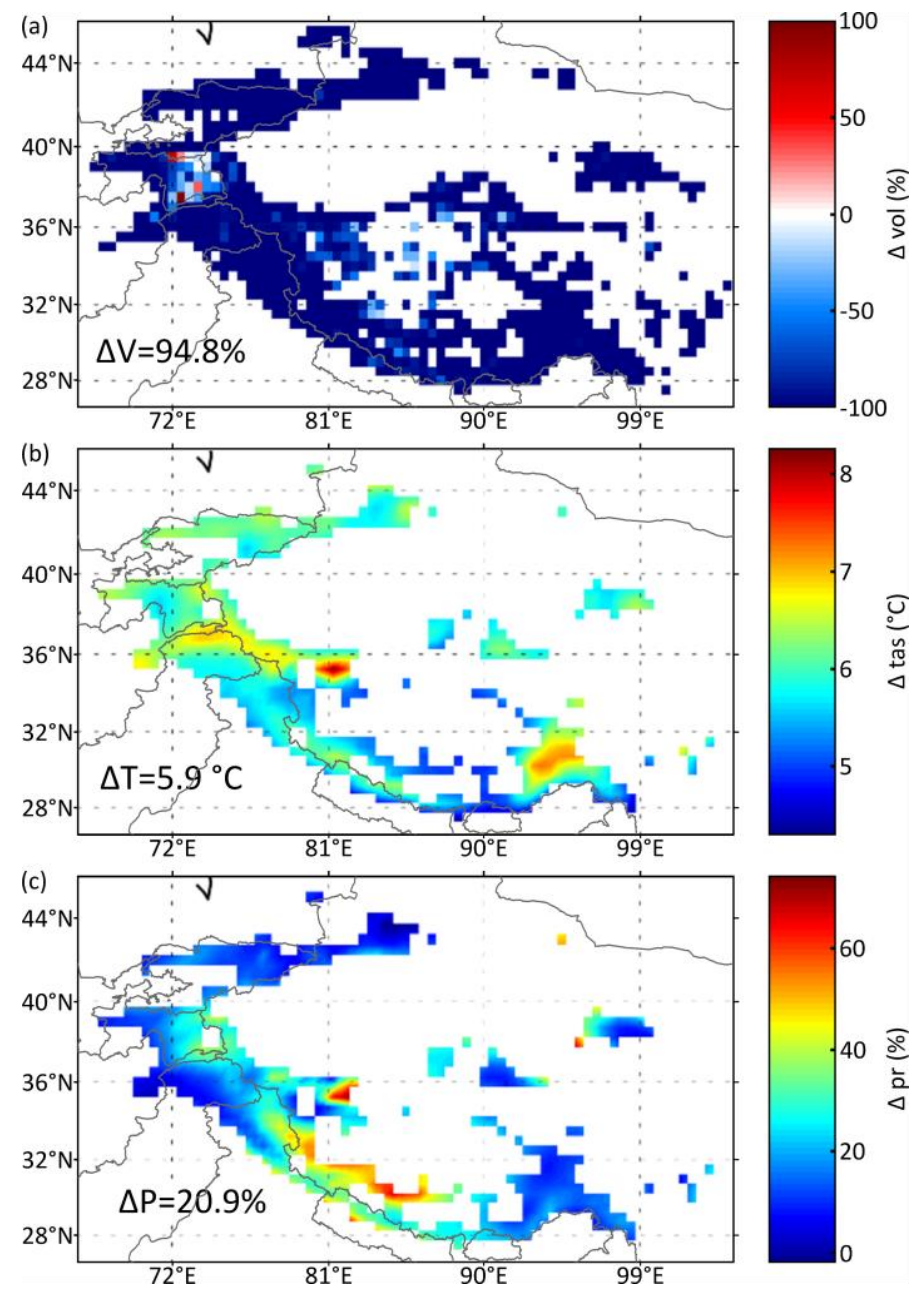

Figure 1. (a) Ensemble mean glacier volume loss, (b) air temperature change, and (c) precipitation change between the historical period (1980-2010) and the end of this century (2067-2097) over glaciated grid points. Glacier volume loss projections were derived from simulations made using an elevation-dependent mass balance scheme in the JULES land surface model under high-end climate change scenarios. JULES has been forced with seven Coupled Model Intercomparison Project Phase 5 (CMIP5) models downscaled using the HadGEM3-A atmosphere-only model. N.B. The anomaly ('hot spot') present in (b) represents an air temperature change of +8.26

${ }^{\circ} \mathrm{C}$, form $-6.69^{\circ} \mathrm{C}$ (historical period mean $1980-2010$ ) to $+1.57^{\circ} \mathrm{C}$ (end of century mean $2067-2097$ ). This large air temperature change is presumed to result from the pixel being snow-covered during the historical period, but landcovered in the future period. Land-covered pixel temperatures are higher due to lower albedo.

Given the need for strong climate adaptation in HMA, a clearer understanding of all components of the hydrological cycle in the high-mountain cryosphere is required ${ }^{7}$. Existing research suggests that rock glaciers - lobate or tongue shaped landforms comprising a continuous and thick active layer covering ice-supersaturated debris and/or pure ice, which slowly creep downslope 8-11 $^{8}$ may constitute increasingly important long-term water stores ${ }^{12}$. Rock glaciers are thought to be climatically more resilient than glaciers owing to the insulating and damping properties of the surficial debris; consequently, their relative hydrological importance vs glaciers may increase 
under future climate warming ${ }^{12}$. Yet, to date, with a few notable exceptions ${ }^{7,13}$, the hydrological role of rock glaciers has been afforded little attention compared to both debris-free glaciers ${ }^{14-16}$ and debris-covered glaciers (ref. 17, and references therein). Indeed, in their recent book chapter, "Status and Change of the Cryosphere in the Extended Hindu Kush Himalayan Region", Bolch et al. ${ }^{18}$ synthesised and evaluated the state of current scientific knowledge regarding changes in the high-mountain cryosphere; however, rock glaciers receive minimal attention. Furthermore, while systematic rock glacier inventory coverage has increased globally, HMA is comparatively datadeficient $^{12}$. Across HMA, with few exceptions ${ }^{19-21}$, rock glacier inventories have been conducted at localised sites, over relatively small spatial scales or are not spatially explicit22-24. Therefore, the distribution and hydrological significance of rock glaciers remains unknown.

\section{Brief methods}

The primary objective was to compile the first systematic rock glacier inventory for the Himalaya (Fig. 2); forming an extension to the existing systematic rock glacier inventory for the Nepalese Himalaya ${ }^{21}$. The inventory in this study was exhaustive, and generated using freely available, fine spatial resolution satellite image data (Google Earth Pro) and a $30 \mathrm{~m}$ digital elevation model (DEM) from NASA SRTM Version 3.0 Global 1 arc second data. A 5\% sample of the full inventory, excluding the Nepalese Himalaya (since sampling was performed in Jones et al. ${ }^{21}$, and the results of that study are integrated here), of the rock glaciers from the West Himalaya, Central Himalaya and East Himalaya was randomly selected and digitised. The dynamic status of landforms was determined considering their presumed ice content and movement, according to an existing morphological classification 8 , established using geomorphic indicators (Table S1). The sampled landforms were classified as: (i) active landforms, containing ice and displaying proxies for movement; (ii) inactive landforms, containing ice and not displaying proxies for recent movement; or (iii) relict landforms, not containing ice nor displaying movement characteristics $^{8,25}$. For simplicity, active and inactive landforms are often collectively termed intact landforms.

The secondary objective was to calculate rock glacier water volume equivalent (WVEQ) and assess rock glacier vs glacier WVEQ across a range of spatial scales. As a consequence of the paucity of detailed sub-surface information for rock glaciers, particularly in HMA, 2-D-arearelated statistics (i.e. empirical thickness-area [H-S] scaling relations) using data from the digitised sample were applied to estimate rock glacier thickness and volume. Empirical H-S relations can be expressed as $\bar{h}=c \cdot S^{\beta}$, where mean feature thickness $\bar{h}(\mathrm{~m})$ is calculated as a function of surface area $S\left(\mathrm{~km}^{2}\right)$ and a scaling parameter c (50) and scaling exponent $\beta(0.2)$ (ref. 26). Feature volumes were determined by $V=\bar{h} \cdot S$. WVEQ was subsequently estimated 
through the multiplication of $\mathrm{V}$ and estimated ice content (\% by vol.) and assuming an ice density conversion factor of $900 \mathrm{~kg} \mathrm{~m}^{-3}$ (ref. 27). Volumetric rock glacier ice content is assumed to be $40-$ $60 \%$ vol. (i.e. lower [40\%], mean [50\%] and upper bounds [60\%]). In order to estimate total landform area and WVEQ for the Himalaya, (i) the database presented here was amalgamated with the existing systematic rock glacier inventory for the Nepalese Himalaya ${ }^{21}$, creating the first comprehensive systematic rock glacier inventory for the Himalaya; and (ii) the digitised sample ( $n=2,070$; this study, $n=933$; Jones et al. ${ }^{21}, \mathrm{n}=1$,137) was extended to the entire population on a regional basis through the upscaling procedure outlined in Fig. S1. Glacier area and volume data for the Himalaya were derived from Frey et al.28. The estimated glacier ice volumes that the WVEQs are based upon were calculated using the GlabTop2 ice-thickness distribution model ${ }^{28}$. A full description of our methods and uncertainty assessment is provided in the Supplementary Information.

\section{Results and discussion}

We identified 24,968 rock glaciers across the Himalaya. Intact and relict rock glaciers accounted for $\sim 65 \%(n=16,334)$ and $\sim 35 \%(n=8,634)$ of the total identified landforms, respectively, based on upscaled estimates (Table 1). Approximately 40\% $(n=10,060)$ of the identified landforms were located in the C-Himalaya, $\sim 30 \%(n=7,573)$ in the E-Himalaya and $\sim 29 \%(n=7,335)$ in the W-Himalaya (Fig. 2; Table 1). The mean density $\left(\mathrm{n} \mathrm{km}^{-2}\right)$ of rock glaciers, when considering terrain $\geq 3,225 \mathrm{~m}$ a.s.l. (i.e. the lowest mean elevation at the front [MEF] of sampled landforms), ranges from 0.06 (W-Himalaya) to 0.08 (East Himalaya/Central Himalaya). Across the Himalaya, rock glacier mean density is 0.05 (intact) and 0.02 (relict) (Table S2). Direct conversion of specific rock glacier area $\left(\mathrm{ha} \mathrm{km}^{-2}\right.$ ) to specific rock glacier density (\%) enables comparison with previous studies. At $1.05 \%$, specific landform density in the Himalaya is lower than other studies in HMA (Table S2). For example, a figure of $\sim 1.50 \%$ is measured in the Northern Tien Shan (Kazakhstan/Kyrgyzstan) ${ }^{24}, \quad 2.65 \%$ in the Zailyiskiy and Kungey Alatau (Kazakhstan/Kyrgyzstan) ${ }^{29}$ and $3.40 \%$ in the Nepalese Himalaya ${ }^{21}$. However, as the Tibetan Plateau constitutes a significant proportion of the terrain $\geq 3,225 \mathrm{~m}$ a.s.l., this may suppress the specific landform density values presented here.

(1)

(1)

(1)


Table 1. Key mean characteristics for intact and relict landforms.

\begin{tabular}{|c|c|c|c|c|c|c|c|c|}
\hline Region & Activity & No. RGs & $(\%)$ & $\begin{array}{c}\text { MEF } \\
\text { (m a.s.l) }\end{array}$ & $\begin{array}{c}\text { MaxE } \\
\text { (m a.s.l) }\end{array}$ & $\begin{array}{l}\text { Area } \\
\left(\mathrm{km}^{2}\right)\end{array}$ & Aspect & $\begin{array}{c}\text { No. RGs } \\
\text { (upscaled) }\end{array}$ \\
\hline \multirow{3}{*}{ E-Himalaya } & Intact & 199 & $53 \%$ & 5,036 & 5,158 & 0.08 & NW & 3,987 \\
\hline & Relict & 179 & $47 \%$ & 4,852 & 4,956 & 0.06 & NW & 3,586 \\
\hline & All & 378 & - & 4,949 & 5,062 & 0.07 & NW & 7,573 \\
\hline \multirow{3}{*}{ C-Himalaya } & Intact & 897 & $67 \%$ & 4,989 & 5,220 & 0.24 & NW & 6,790 \\
\hline & Relict & 432 & $33 \%$ & 4,599 & 4,785 & 0.14 & NW & 3,270 \\
\hline & All & 1,329 & - & 4,863 & 5,078 & 0.21 & NW & 10,060 \\
\hline \multirow{3}{*}{ W-Himalaya } & Intact & 275 & $76 \%$ & 4,564 & 4,729 & 0.15 & NW & 5,557 \\
\hline & Relict & 88 & $24 \%$ & 4,312 & 4,470 & 0.13 & $\mathrm{~N}$ & 1,778 \\
\hline & All & 363 & - & 4,503 & 4,666 & 0.15 & NW & 7,335 \\
\hline \multirow{3}{*}{ Total } & Intact & 1,371 & $66 \%$ & 4,911 & 5,112 & 0.20 & NW & 16,334 \\
\hline & Relict & 699 & $34 \%$ & 4,628 & 4,789 & 0.12 & NW & 8,634 \\
\hline & All & 2,070 & - & 4,815 & 5,003 & 0.17 & NW & 24,968 \\
\hline
\end{tabular}

121

122

123

MaxE = Maximum elevation of the rock glacier

$\mathrm{MEF}=$ Minimum elevation of the front

124

125

126

127

128

129

130

131

132

133

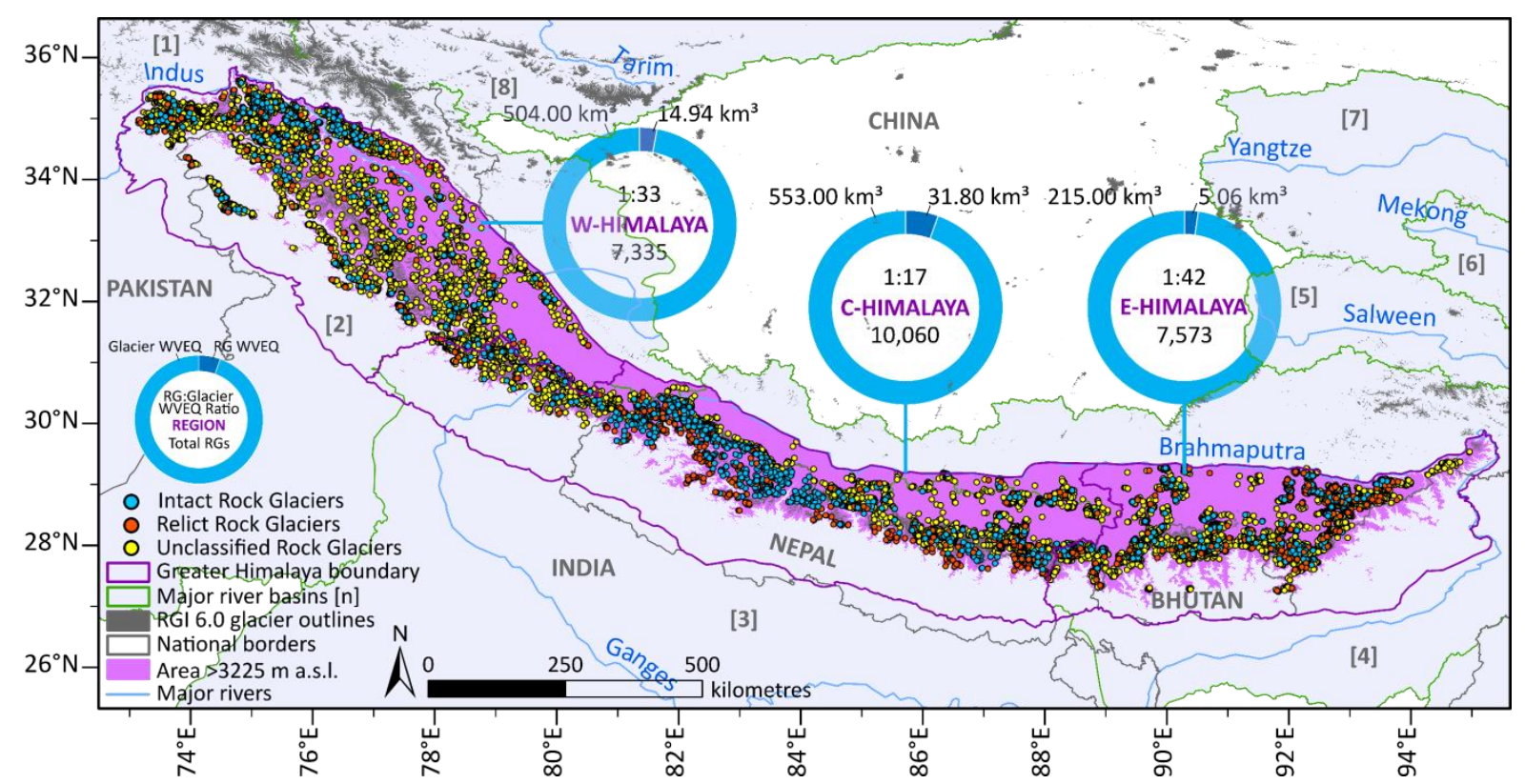

Figure 2. Map of the Himalaya showing the distribution of rock glaciers. Rock glaciers with unclassified dynamic status (i.e. landforms that were not digitised) are included here for completeness. The total rock glacier number, rock glacier and glacier WVEQ and rock glacier: glacier WVEQ ratios for the West, Central and East Himalaya regions are shown. These regions are derived from Bolch et al. ${ }^{30}$. Note that rock glacier WVEQ assumes the 50\% (average) ice content by volume. The area $>3,225 \mathrm{~m}$ a.s.l. represents the lowermost MEF of rock glaciers across the Himalaya. The major river basin boundaries are shown: [1] Amu Darya, [2] Indus, [3] Ganges, [4] Brahmaputra, [5] Salween, [6] Mekong, [7] Yangtze and [8] Tarim.

Across the Himalaya, the sampled rock glaciers $(n=2,070)$ are situated within an elevation range of 3,225 to 5,766 $\mathrm{m}$ a.s.l. (MEF), with $87 \%$ found between 4,200 and 5,400 $\mathrm{m}$ a.s.l. This is broadly consistent with that previously reported for the HKH $(3,554-5,735 \mathrm{~m} \text { a.s.l.) })^{22}$. At the regional- 
scale, mean MEFs for the East (4,949 \pm 256 m a.s.l.), Central (4,863 $\pm 372 \mathrm{~m}$ a.s.l.) and West

137 Himalaya (4,503 $\pm 422 \mathrm{~m}$ a.s.l.) demonstrate a decreasing westward trend in rock glacier 138 elevation across the Himalaya (Table 1; Fig. S2). This trend remains consistent when considering 139 intact and relict rock glaciers separately (Table 1). We report a pronounced south-to-north 140 increase in rock glacier MEF across the Himalaya, with rock glaciers found several hundreds of 141 metres higher on the northern slopes (see also Schmid et al. ${ }^{22}$ ) (Fig. S2). As expected, across the 142 Himalaya intact rock glaciers are located at statistically higher elevations than relict rock glaciers 143 when considering MEFs (ANOVA: F-value [2, 2064] = 16.19, $\mathrm{p}=<0.001$ ); Tukey post hoc testing 144 shows that this finding translates to the regional-scale (W-Himalaya: Diff $=252, p=<0.001$; C145 Himalaya: Diff: 390, $\mathrm{p}=<0.001$; E-Himalaya: Diff $=184, \mathrm{p}=<0.001)$. Across the Himalaya, intact 146 rock glaciers are predominantly found above 4,800 $\mathrm{m}$ a.s.l. (MEF) (65\%) and relict rock glaciers 147 below 4,800 m a.s.l. (67\%). Furthermore, intact rock glaciers are clustered between 4,400-5,400 $148 \mathrm{~m}$ a.s.l. (84\%) and relict rock glaciers between 4,200-5,200 $\mathrm{m}$ a.s.l. (79\%). This result provides 149 validation for the dynamic status classification, given the expected vertical progression of suitable 150 habitats for rock glacier development and persistence linked to climatic warming since the Little Ice Age.

Across the Himalaya rock glaciers are primarily situated on north-facing slopes (Table 1), particularly clustering around north-western slopes $\left(\bar{x}=321^{\circ}\right)$. Regionally, a greater proportion of rock glaciers are situated within the northern vs southern aspect quadrant (Table S3). Additionally, rock glaciers situated within the northern aspect quadrant occur at lower elevations than those found within the southern aspect quadrant (Fig. S3). Figure S3 also illustrates the clustering of rock glaciers around northerly aspects. The results presented here corroborate the findings of other northern hemisphere studies, which have detailed similar relationships ${ }^{20,31-33}$. Therefore, it is reasonable to assume that northerly aspects with their reduced solar insolation enable rock glacier formation and preservation at lower elevations than other aspects, in particular, southerly aspects.

In the study region, sampled rock glaciers $(\mathrm{n}=2,070)$ have a total surface area of $359.95 \mathrm{~km}^{2}$ with intact and relict landforms constituting $277.78 \mathrm{~km}^{2}(\sim 77 \%)$ and $82.18 \mathrm{~km}^{2}(\sim 23 \%)$, respectively. Total rock glacier surface coverage is largest in the C-Himalaya $\left(278.70 \mathrm{~km}^{2}\right)$, succeeded by the $\mathrm{W}$-Himalaya $\left(53.76 \mathrm{~km}^{2}\right)$ and E-Himalaya $\left(27.50 \mathrm{~km}^{2}\right)$. Here, when reporting rock glacier sample totals, it is important to note the proportionally larger sample size for the C-Himalaya, which is the result of the amalgamation database presented here with the existing systematic rock glacier inventory for the Nepalese Himalaya ${ }^{21}$. Correspondingly, the mean and median surface area is greatest in the C-Himalaya $\left(\bar{x}=0.21 \mathrm{~km}^{2}\right.$ and $\left.\tilde{x}=0.12 \mathrm{~km}^{2}\right)$ followed by the W-Himalaya and EHimalaya (Table 1). Across the Himalaya the area of individual sampled landforms varies between 
$3.54 \mathrm{~km}^{2}$ and $0.004 \mathrm{~km}^{2}$, with 1,069 landforms $\geq 0.1 \mathrm{~km}^{2}$ in area. Onaca et al. ${ }^{34}$ speculate that rock glaciers in the highest mountain ranges are comparatively larger than those situated in lower mountain ranges, linked to the longevity of active dynamic status. Additionally, given the importance of debris-supply to rock glacier development and persistence, Hewitt ${ }^{35}$ notes that as interfluve height increases, more and larger rock glaciers are likely below it. In the high and deeply incised ranges of the Himalaya ${ }^{36}$, it is reasonable to argue that these topographic factors influence the size of rock glaciers. We report that several rock glaciers have similar areal coverage to the largest examples found elsewhere; for example, $1.95 \mathrm{~km}^{2}$ (ref. 24) and $3.60 \mathrm{~km}^{2}$ (ref. 19) in Central Asia. Furthermore, the area of rock glaciers $\left(\bar{x}=0.17 \mathrm{~km}^{2}\right)$ exceeds that of rock glaciers found in other mountain ranges globally ${ }^{12}$. In the Himalaya, estimated total upscaled rock glacier area is $3,747 \mathrm{~km}^{2}$, representing $\sim 16 \%$ of the area covered by glaciers in the same region $\left(22,829 \mathrm{~km}^{2}\right)$. Regionally, rock glacier coverage ranged between $550.87 \mathrm{~km}^{2}$ and $2,109.63 \mathrm{~km}^{2}$ in the EHimalaya and C-Himalaya, respectively.

We show that the sampled rock glaciers contain an estimated WVEQ of $5.19 \pm 1.04 \mathrm{~km}^{3}$ with upscaled estimates for the population of $51.80 \pm 10.36 \mathrm{~km}^{3}$ (Fig. 2; Table S4). Glacier WVEQ in the Himalaya is estimated to be $1,272 \mathrm{~km}^{3}$ (ref. 28) (Table 2), which translates to a ratio of rock glacier to glacier WVEQ of 1:244. However, this ratio decreases to 1:24 when upscaled rock glacier WVEQs are considered.

Table 2. WVEQs $\left(\mathrm{km}^{3}\right)$ for rock glaciers (sampled and upscaled) and ice glaciers, regionally and across the Himalaya (total). Additionally, the rock glacier to ice glacier ratios are directly compared. Rock glacier WVEQs assume the 50\% (average) ice content by volume. Values are reported to two decimal places. Ice glacier WVEQ data are derived from Frey et al.28.

\begin{tabular}{lcccccc}
\hline \multirow{2}{*}{ Region } & \multicolumn{2}{c}{ Ice-debris landform } & \multicolumn{2}{c}{ Ice glacier } & \multicolumn{2}{c}{$\begin{array}{c}\text { Ratio: rock glacier: Ice } \\
\text { glacier WVEQ }\end{array}$} \\
\cline { 2 - 7 } & $\begin{array}{c}\text { Sample } \\
\text { WVEQ }\left(\mathrm{km}^{3}\right)\end{array}$ & $\begin{array}{c}\text { Upscaled } \\
\text { WVEQ }\left(\mathrm{km}^{3}\right)\end{array}$ & $\begin{array}{c}\text { Area } \\
\left(\mathrm{km}^{2}\right)\end{array}$ & $\begin{array}{c}\text { WVEQ } \\
\left(\mathrm{km}^{3}\right)\end{array}$ & $\begin{array}{c}\text { Sample } \\
\text { ratio }\end{array}$ & $\begin{array}{c}\text { Upscaled } \\
\text { ratio }\end{array}$ \\
\hline E - Himalaya & 0.25 & 5.06 & $3,946.00$ & 215.00 & $1: 851$ & $1: 42$ \\
C - Himalaya & 4.20 & 31.80 & $9,940.00$ & 553.00 & $1: 131$ & $1: 17$ \\
W - Himalaya & 0.74 & 14.94 & $8,943.00$ & 504.00 & $1: 681$ & $1: 33$ \\
Total & 5.19 & 51.80 & $22,829.00$ & $1,272.00$ & $1: 244$ & $1: 24$ \\
\hline
\end{tabular}

The estimated glacier ice volumes used to calculate WVEQ are calculated from the GlabTop2 icethickness distribution model ${ }^{28}$. However, in the Himalaya, WVEQ ranges between 1,237 and 1,909 $\mathrm{km}^{3}$ depending on the choice of method used to estimate glacier volume ${ }^{28}$. For the different methods rock glacier to glacier WVEQ ratios for the Himalaya varied between 1:23 and 1:36 
201 (Table S5). Regardless of the method chosen, across the Himalaya rock glaciers constitute

202 hydrologically valuable long-term water stores.

203

204

205

206

207

208

209

210

211

212

213

214

215

216

217

218

219

220

221

222

223

224

225

226

227

228

229

230

231

232

233

234

235

236

\section{Conclusion}

Here, we have presented the first systematic inventory of rock glaciers in the Himalaya and shown that there are approximately 25,000 rock glaciers, with an areal coverage of $\sim 3,747 \mathrm{~km}^{2}$. A rock glacier sample $(n=2,070)$ across the Himalaya showed that $\sim 65 \%$ were intact and $\sim 35 \%$ relict. Rock glaciers were estimated to contain a WVEQ of $51.80 \pm 10.36 \mathrm{~km}^{3}$; equivalent to between 41 and 62 trillion litres. The comparative importance of rock glaciers vs glaciers (rock glacier to glacier WVEQ ratio) in the Himalaya was 1:24, ranging from 1:42 to 1:17 in the E-Himalaya and C-Himalaya, respectively. Additionally, for the first time we evaluate the influence of glacier model choice on rock glacier to glacier WVEQ ratios. Across the Himalaya rock glacier to glacier WVEQ ratios ranged between 1:23 (slope-dependent thickness estimation) and 1:36 (V-S scaling relation [LIGG et al., 1988]). We conclude that rock glaciers within the Himalaya constitute hydrologically valuable long-term water stores and given continued climatically-driven glacier recession and mass loss the relative hydrological value of rock glaciers in mountain regions will likely become increasingly important. Prior to this study, knowledge of Himalayan-wide rock glacier characteristics were missing, and so our work provides the first scientific baseline from which Himalayan-wide rock glacier response to climate change can be assessed.

\section{Methods}

\section{Earth observation data}

In the Google Earth Pro platform (version 7.1.8.3036), we used publicly available current and archived satellite image data, including fine spatial resolution CNES/Airbus (e.g., SPOT and Pleiades) and DigitalGlobe-derived imagery (e.g., Worldview-1 and 2, and QuickBird), to compile the systematic rock glacier inventory for the Himalaya region. A $\sim 30 \mathrm{~m}$ resolution DEM from NASA SRTM Version 3.0 Global 1 arc second data (see https://lpdaac.usgs.gov/products/srtmgl1v003/) was used (herein SRTM30 DEM).

\section{Rock glacier data}

A gridded search methodology approach was employed to ensure inventory compilation was systematic and exhaustive. In ESRI ArcGIS (version 10.6.0.8321), a gridded overlay of $40 \mathrm{~km}^{2}$ grid squares covering the study region was created. This shapefile was subsequently imported into Google Earth Pro, and each grid square was visually surveyed on an individual basis. Rock glaciers were identified according to geomorphic indicators (Table S6) and pinned within Google Earth Pro, and an initial point-based inventory was created for the Himalaya. In ArcGIS, the point-based 
inventory was split into the sub-regions (i.e. W-Himalaya, C-Himalaya and E-Himalaya) as defined by Bolch et al. ${ }^{30}$ (Fig. 2). A 5\% sample of the identified landforms from each region (W-Himalaya, $\mathrm{n}=363$; C-Himalaya, $\mathrm{n}=192$; E-Himalaya, $\mathrm{n}=378$ ) were randomly selected within ArcGIS. Note that the Nepalese Himalaya, which constitutes a significant proportion of the C-Himalaya, has previously been inventoried by the current authors ${ }^{21}$; therefore, the above-described C-Himalaya sample was sourced from newly inventoried landforms only - i.e. excludes the existing Nepalese Himalaya inventory.

The geographic boundaries of the selected $\sim 5 \%$ regional samples were digitised within Google Earth Pro, forming a polygonised inventory within which more detailed spatial attributes were measured. Multi-temporal satellite image data were used for this purpose (2000-2019), reducing mapping uncertainties associated with poor quality image data, affected by long-cast shadows on steep north-facing slopes, cloud cover and snow cover, for example ${ }^{21}$. For feature boundary digitisation, we adopted the approach of Scotti et al. ${ }^{32}$, as previously applied in Jones et al. ${ }^{21}$. Here, the outline of the entire feature surface was delineated, from the rooting zone (i.e. MaxE) to the base of the front slope (i.e. MEF) (Fig. S4). Where multiple landforms coalesce into a single body, digitisation was challenging. In this study, "when the frontal lobes of two (or more) rock glaciers originating from distinct source basins join downslope, we consider the two components as separate bodies. Where the limits between lobes are unclear and the lobes share other morphological characteristics (e.g., dynamic status [i.e. degree of activity] and vegetation cover), we classify the whole system as a unique rock glacier" 32 . Further, where rock glaciers grade into upslope landforms, for instance where a rock glacier is gradually developing from a terminal or lateral moraine, "a clear distinction between the two landforms cannot be set and we delineated the whole body (i.e. moraine plus rock glacier)"32. Both quantitative and qualitative attributes were extracted and recorded for each feature in the polygonised inventory (see Table S6).

In ArcGIS, the present study used the Universal Transverse Mercator (UTM) WGS 84 projected coordinate system - UTM Zone $43 \mathrm{~N}$ to $46 \mathrm{~N}$ - in order to quantify the morphometric characteristics of all shapefiles (e.g., feature length, width, area [and thus WVEQ]). Digitised landforms were reprojected to the WGS 84 coordinate system and exported to KML formatted files. Rock glacier lengths (parallel to the flow) were manually digitised within Google Earth Pro. Based upon an existing methodology 37 , in order to account for width variation along the length of each feature widths (perpendicular to length) were digitised at $50 \mathrm{~m}$ intervals and mean width calculated in ArcGIS (Figure S4). Landforms were categorised into tongue-shaped or lobateshaped, where the length: width ratio is $>1$ or $<1$, respectfully ${ }^{38}$. 
Applying ArcGIS surface raster functions (Zonal Statistics) the digitised landforms were overlaid onto the SRTM30 DEM and the minimum, maximum, range and mean elevation extracted for each feature. In ArcGIS, an aspect raster surface was created using the SRTM DEM as the input and clipped to the digitised feature boundaries. As a circular parameter, feature mean aspect (i.e. the mean aspect of the raster pixels within each digitised feature) cannot be calculated using simple zonal statistics (i.e. the mean of $0^{\circ}$ and $359^{\circ}$ cannot be $180^{\circ}$ [Davis, 1986 as cited in Janke et al..$^{9}$ ). The vector mean aspect $(\bar{\theta})$ was calculated in R (version 3.1.2, R Core Team, Vienna, Austria) using Equation 1 and categorised into eight classes - N, NE, E, SE, S, SW, W and NW.

Equation 1. $S=\sum \sin \theta, C=\sum \cos \theta \quad \bar{\theta}=\arctan \frac{S}{C}$

In Google Earth Pro the dynamic status of digitised landforms was determined considering their presumed ice content and movement, in accordance with the morphological classification by Barsch (1996), using the geomorphic indicators previously outlined (Table S1). In the present study, rock glaciers were categorised as relict landforms (no longer contain ice nor display movement) and active landforms (contain ice and display movement) and inactive landforms (contain ice but no longer display movement) ${ }^{8,25}$. Here, rock glaciers refer to intact landforms, i.e. active and inactive landforms combined.

As a consequence of the paucity of detailed subsurface information for rock glaciers, 2-D-arearelated statistics (i.e. empirical H-S relations) were applied in this study to predict rock glacier thickness and derive volume. Empirical H-S relations can be expressed as $\bar{h}=c \cdot S^{\beta}$, where mean feature thickness $\bar{h}(\mathrm{~m})$ is calculated as a function of surface area $S\left(\mathrm{~km}^{2}\right)$ and a scaling parameter $c(50)$ and scaling exponent $\beta(0.2)$ (ref. 26). Feature volumes were determined by $V=\bar{h} \cdot S$. WVEQ was subsequently estimated through the multiplication of $V$ and estimated ice content (\% by vol.) and assuming an ice density conversion factor of $900 \mathrm{~kg} \mathrm{~m}^{-3}$ (ref. 27). Here, a volumetric rock glacier ice content of 40-60\% vol. (i.e. lower [40\%], mean [50\%] and upper bounds [60\%]) was assumed in accordance with previous studies $12,21,26,40,41$ - consistent with in situ data derived from different climatic regions worldwide ${ }^{42-46}$.

In the present study, the dataset generated through the application of the above-described methodology and pre-existing rock glacier inventory of the Nepalese Himalaya were amalgamated, creating the first systematic inventory of rock glaciers in the Himalaya. In order to estimate rock glacier area and WVEQ in the Himalaya, the digitised sample $(n=2,070)$ was extended to the entire population $(n=24,968)$ on a regional basis through the upscaling procedure (Fig. S1). 


\section{$310 \quad$ Glacier data}

311 Glacier data for the study region were derived from Frey et al. ${ }^{28}$. Figure 1 in Frey et al. ${ }^{28}$ describes

312 the sources of the original glacier outlines. The estimated ice volumes, which the WVEQs are

313 based upon, were calculated using the Glacier bed Topography (GlabTop2) ice-thickness

314 distribution model ${ }^{28}$. Regional data are presented for the W-Himalaya, C-Himalaya and E-

315 Himalaya using the same geographic boundaries (i.e. Bolch et al. ${ }^{30}$ ) as in this study, enabling the

316 direct comparison of rock glacier and glacier results.

\section{Uncertainty}

319 In order to quantify the uncertainties associated with the identification, digitisation and 320 classification of features of interest 47 , we detailed the degree of 'uncertainty' through the 321 application of a Certainty Index score, adapted from Schmid et al. ${ }^{22}$, for each digitised feature 322 (Table S7). Additionally, as arguably the most conspicuous morphological manifestation of 323 permafrost in high mountain systems, rock glaciers are often strongly associated with the lower 324 limit of permafrost distribution. Consequently, here values were extracted from the Permafrost 325 Zonation Index (PZI) - a global index that helps to constrain and visualise areas of likely 326 permafrost occurrence ${ }^{48}$ - for each digitised feature, and the agreement between rock glacier 327 spatial distribution and their associated PZI values was assessed. The uncertainty associated with 328 the calculation of rock glacier WVEQ using the above-described empirical H-S relation has 329 previously been discussed at length7 ${ }^{7}$. Lastly, the influence of methodology selection upon glacier 330 ice volume estimations (and thus WVEQs) was quantitatively assessed using rock glacier to 331 glacier WVEQ ratios related to a range of different approaches: three area-volume relations, one 332 slope-dependent estimation method, and two ice-thickness distribution models (Table S5). 
Pritchard, H. D. Asia's shrinking glaciers protect large populations from drought stress. Nature 569, 649-654 (2019).

Hock, R. et al. GlacierMIP - A model intercomparison of global-scale glacier mass-balance models and projections. Journal of Glaciology 65, 453-467 (2019). Shannon, S. et al. Global glacier volume projections under high-end climate change scenarios. The Cryosphere 13, 325-350 (2019). Kraaijenbrink, P. D. A., Bierkens, M. F. P., Lutz, A. F. \& Immerzeel, W. W. Impact of a global temperature rise of 1.5 degrees Celsius on Asia's glaciers. Nature 549, 257-260 (2017). Smith, T. \& Bookhagen, B. Changes in seasonal snow water equivalent distribution in High Mountain Asia (1987 to 2009). Science Advances 4, e1701550 (2018).

Huss, M. \& Hock, R. Global-scale hydrological response to future glacier mass loss. Nature Climate Change 8, 135-140 (2018). Jones, D. B., Harrison, S., Anderson, K. \& Whalley, W. B. Rock glaciers and mountain hydrology: A review. Earth-Science Reviews 193, 66-90 (2019).

Barsch, D. Rockglaciers: Indicators for the Present and Former Geoecology in High Mountain Environments. 1 edn, (Springer-Verlag Berlin Heidelberg, 1996).

Haeberli, W. et al. Permafrost creep and rock glacier dynamics. Permafrost and Periglacial Processes 17, 189-214 (2006).

Martin, H. E. \& Whalley, W. B. Rock glaciers. Part 1: Rock glacier morphology: Classification and distribution. Progress in Physical Geography 11, 260-282 (1987).

11 Berthling, I. Beyond confusion: Rock glaciers as cryo-conditioned landforms. Geomorphology 131, 98-106 (2011). Jones, D. B., Harrison, S., Anderson, K. \& Betts, R. A. Mountain rock glaciers contain globally significant water stores. Scientific Reports 8, 2834 (2018).

36415 Irvine-Fynn, T. D. L., Hodson, A. J., Moorman, B. J., Vatne, G. \& Hubbard, A. L. Polythermal glacier hydrology: A review. Reviews of Geophysics 49, RG4002 (2011). 299-328 (1998). 
17 Fyffe, C. L. et al. Do debris-covered glaciers demonstrate distinctive hydrological behaviour compared to clean glaciers? Journal of Hydrology 570, 584-597 (2019).

Bolch, T. et al. in The Hindu Kush Himalaya Assessment: Mountains, Climate Change, Sustainability and People (eds Philippus Wester, Arabinda Mishra, Aditi Mukherji, \& Arun Bhakta Shrestha) 209-255 (Springer International Publishing, 2019).

Blöthe, J. H., Rosenwinkel, S., Höser, T. \& Korup, O. Rock-glacier dams in High Asia. Earth Surface Processes and Landforms 44, 808-824 (2019).

Baral, P., Haq, M. A. \& Yaragal, S. Assessment of rock glaciers and permafrost distribution in Uttarakhand, India. Permafrost and Periglacial Processes 31, 31- 56 (2020).

Jones, D. B. et al. The distribution and hydrological significance of rock glaciers in the Nepalese Himalaya. Global and Planetary Change 160, 123-142 (2018).

Schmid, M. O. et al. Assessment of permafrost distribution maps in the Hindu Kush Himalayan region using rock glaciers mapped in Google Earth. The Cryosphere 9, 2089-2099 (2015). Regmi, D. in Proceedings of the Ninth International Conference on Permafrost. 1475-1480. Bolch, T. \& Gorbunov, A. P. Characteristics and origin of rock glaciers in Northern Tien Shan (Kazakhstan/Kyrgyzstan). Permafrost and Periglacial Processes 25, 320-332 (2014).

Haeberli, W. Creep of mountain permafrost: Internal structure and flow of alpine rock glaciers. Vol. 77 (1985).

Brenning, A. Climatic and Geomorphological Controls of Rock Glaciers in the Andes of Central Chile: Combining Statistical Modelling and Field Mapping Ph.D thesis, Humboldt-Universität zu Berlin, (2005).

$$
\text { Paterson, W. S. B. The Physics of Glaciers. 3rd Edition edn, (Butterworth-Heinemann, 1994). }
$$

Frey, H. et al. Estimating the volume of glaciers in the Himalayan-Karakoram region using different methods. The Cryosphere 8, 2313-2333 (2014). Water Resources in Asia. (eds L. Braun, W. Hagg, I.V. Severskiy, \& G.J. Young) 132-144 (IHP/HWRP-Berichte, 2009).

Bolch, T. et al. The state and fate of Himalayan glaciers. Science 336, 310-314 (2012).

Seppi, R. et al. Inventory, distribution and topographic features of rock glaciers in the southern region of the Eastern Italian Alps (Trentino). Geografia Fisica e Dinamica Quaternaria 35, 185197 (2012). Scotti, R., Brardinoni, F., Alberti, S., Frattini, P. \& Crosta, G. B. A regional inventory of rock glaciers and protalus ramparts in the central Italian Alps. Geomorphology 186, 136-149 (2013).

33 Ishikawa, M., Watanabe, T. \& Nakamura, N. Genetic differences of rock glaciers and the discontinuous mountain permafrost zone in Kanchanjunga Himal, Eastern Nepal. Permafrost and Periglacial Processes 12,243-253 (2001). 
40434 Onaca, A., Ardelean, F., Urdea, P. \& Magori, B. Southern Carpathian rock glaciers: Inventory,

405 distribution and environmental controlling factors. Geomorphology 293, 391-404 (2017).

40635 Hewitt, K. in Glaciers of the Karakoram Himalaya: Glacial Environments, Processes, Hazards and 407 Resources (ed K. Hewitt) 267-289 (Springer Netherlands, 2014).

40836 Scherler, D., Bookhagen, B. \& Strecker, M. R. Spatially variable response of Himalayan glaciers to 409 climate change affected by debris cover. Nature Geoscience 4, 156-159 (2011).

41037 Frauenfelder, R., Haeberli, W. \& Hoelzle, M. in Proceedings 8th International Conference on $411 \quad$ Permafrost. Swets and Zeitlinger, Lisse. 253-258.

41238 Guglielmin, M. \& Smiraglia, C. in Permafrost - Seventh International Conference (Proceedings). 413 (Collection Nordicana).

41439 Janke, J. R., Regmi, N. R., Giardino, J. R. \& Vitek, J. D. in Treatise on Geomorphology Vol. 8, Glacial 415 and Periglacial Geomorphology (eds J. Shroder, R. Giardino, \& J. Harbor) 238-273 (Academic $416 \quad$ Press, 2013).

$41740 \quad$ Rangecroft, S., Harrison, S. \& Anderson, K. Rock glaciers as water stores in the Bolivian Andes: 418 An assessment of their hydrological importance. Arctic, Antarctic, and Alpine Research 47, 8998 (2015).

Bodin, X., Rojas, F. \& Brenning, A. Status and evolution of the cryosphere in the Andes of Santiago (Chile, $33.5^{\circ}$ S.). Geomorphology 118, 453-464 (2010). Hausmann, H., Krainer, K., Brückl, E. \& Ullrich, C. Internal structure, ice content and dynamics of Ölgrube and Kaiserberg rock glaciers (Ötztal Alps, Austria) determined from geophysical surveys. Austrian Journal of Earth Sciences 105, 12-31 (2012). (2002). Hausmann, H., Krainer, K., Brückl, E. \& Mostler, W. Internal structure and ice content of Reichenkar rock glacier (Stubai Alps, Austria) assessed by geophysical investigations. Permafrost and Periglacial Processes 18, 351-367 (2007).

43346 Elconin, R. F. \& LaChapelle, E. R. Flow and internal structure of a rock glacier. Journal of Glaciology 43, 238-244 (1997).

43547 Brardinoni, F., Scotti, R., Sailer, R. \& Mair, V. Evaluating sources of uncertainty and variability in rock glacier inventories. Earth Surface Processes and Landforms 44, 2450-2466 (2019). The Cryosphere 6, 221-233 (2012). 
440 Rock glaciers represent hidden water stores in the Himalaya

441 Supplementary information

442

443 Supplementary figures 1-4

444 Supplementary tables $1-7$

445 Rock glacier inventory (KML formatted file)

446

447

448

449

450

451

452

453

454

455

456

457

458

459

460

461

462

463

464

465

466

467

468

469

470

471

472

473

474

475

476

477

478

479

480

481

482

483

484

485

486

487

488

489

490

491

492 
494 Supplementary Figure 1. Flow diagram detailing the process for (a) upscaling of rock glacier surface area, and (b)

495 upscaling of rock glacier WVEQ. Both are derived from the digitised sample.

496 Supplementary Figure 2. MEF of the sampled rock glacier across the Himalaya.

497 Supplementary Figure 3. Scatterplot of mean aspect $\left({ }^{\circ}\right)$ against MEF showing the distribution of intact and relict 498 landforms across the Himalaya. The two dashed lines are $3^{\text {rd }}$ order polynomial fit (upper line: intact landforms; 499 lower line: relict landforms).

500 Supplementary Figure 4. Annotated diagram of landform attributes, Nepal (2906’20.36” N, 8306’57.39” E). 501 Image data: Google Earth, DigitalGlobe; imagery date: 05 November 2011. Figure adopted from Jones et al. (ref. 21). 
(a) Additional rock glaciers $=$ total rock glaciers - subsample rock glaciers

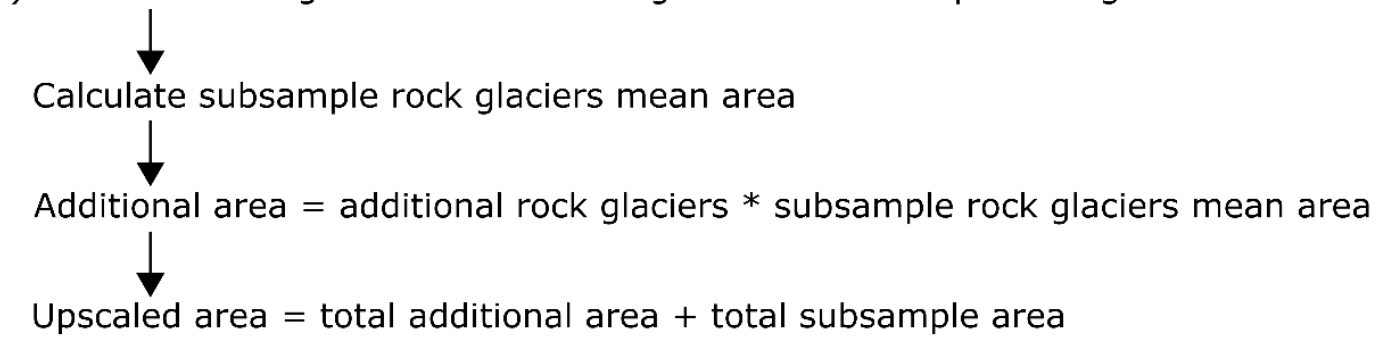

(b) Subsample proportion (\%) of intact or relict landforms

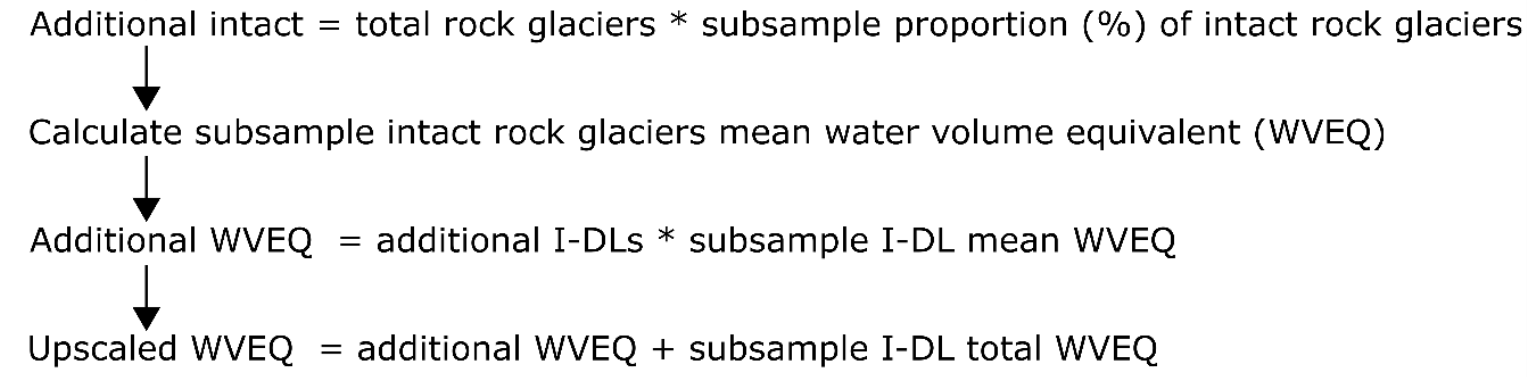


580

581

582

583

584

585

586

587

588

589

590

591

592

593

594

595

596

597

598

599

600

601

602

603

604

605

606

607

608

609

610

611

612

613

614

615

616

617

618

619

620

621

622

623

624

625

626

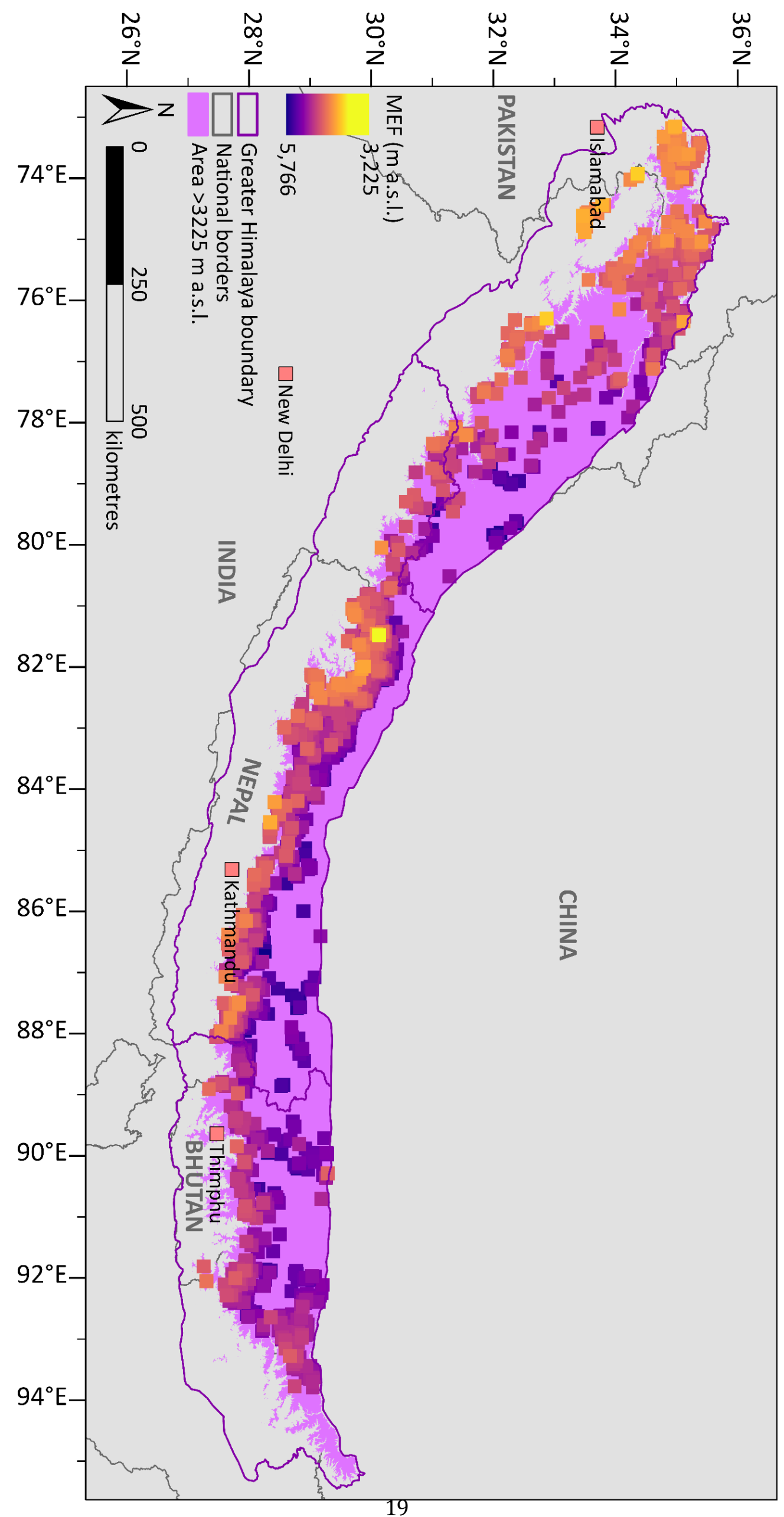




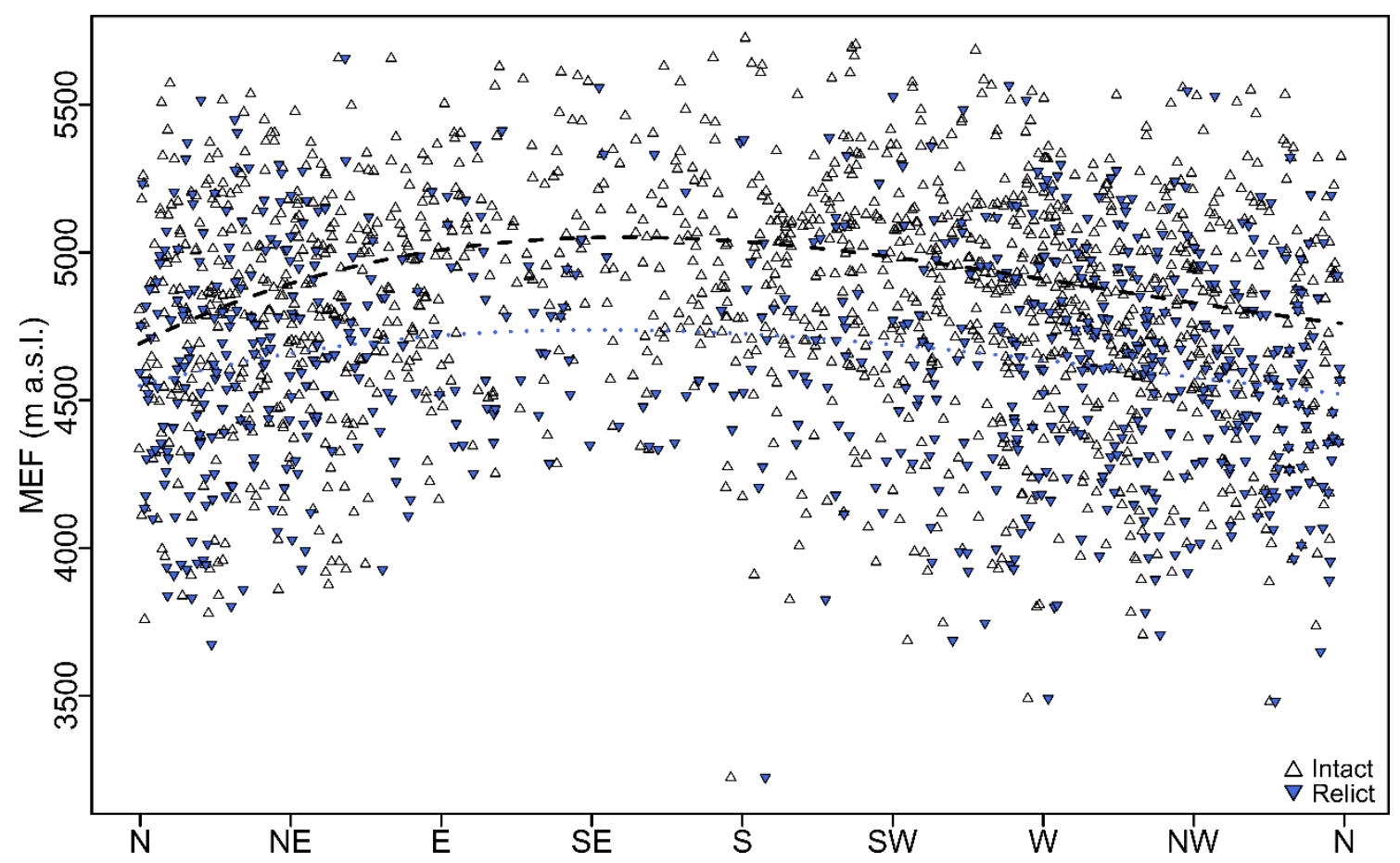

628

629

630

631

632

633

634

635

636

637

638

639

640

641

642

643

644

645

646

647

648

649

650

651

652

653

654

655

656

657

658

659 


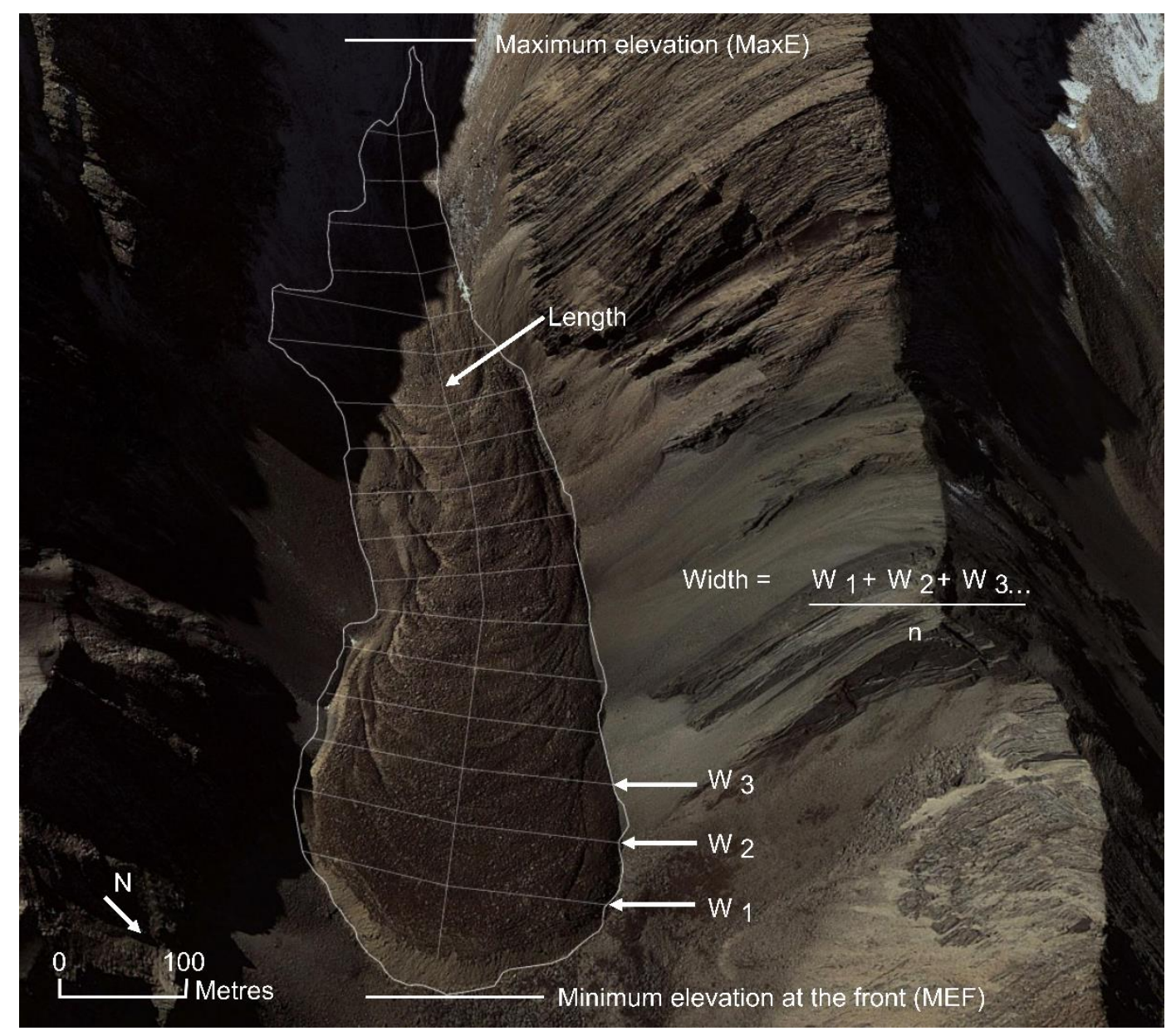

660

661

662

663

664

665

666

667

668

669

670

671

672

673

674

675

676

677

678

679

680

681

682

683

684

685 
687 Supplementary Table 1. Geomorphic indicators used to identify rock glaciers and their activity status.

688 Supplementary Table 2. Rockglacier proportion, proportional area $\geq 3,225 \mathrm{~m}$ a.s.l., rock glacier density 689 and rock glacier specific area across for the sub-regions of the Himalaya. Where appropriate, values are 690 reported to two decimal places.

691 Supplementary Table 3. Regional aspect classification of rock glaciers into north- $\left(292.5\right.$ to $\left.67.5^{\circ}\right)$ and 692 south- (112.5 to $\left.247.5^{\circ}\right)$ facing aspect quadrants.

693 Supplementary Table 4. Ice volume $\left(\mathrm{km}^{3}\right)$ and corresponding WVEQs $\left(\mathrm{km}^{3}\right)$ for both the sampled and 694 upscaled intact rock glaciers, regionally and across the Himalaya (total). These calculations encompass 695 a range of ice content by volume estimates with a lower (40\%), average (50\%) and upper (60\%) bound. 696 Values are reported to two decimal places.

697 Supplementary Table 5. WVEQs $\left(\mathrm{km}^{3}\right)$ for ice glaciers derived using different methodologies, 698 regionally and across the Himalaya (total). The upscaled intact rock glacier to ice glacier ratios are 699 directly compared for each methodology. Rock glacier WVEQs used in the ratio calculations assume the $50 \%$ (average) ice content by volume. Values are reported to two decimal places. Ice glacier WVEQ data are derived from Frey et al. (ref. 1). Supplementary Table 6. Attributes recorded for each feature in the polygonised inventory, with attribute explanation. This table has been adapted from Jones et al. (ref. 2). Supplementary Table 7. Certainty index applied to each rock glacier. 


\begin{tabular}{|c|c|c|}
\hline Geomorphic Indicator & Active & Relict \\
\hline Surface Flow Structure & $\begin{array}{l}\text { Defined furrow-and-ridge } \\
\text { topography }\end{array}$ & $\begin{array}{l}\text { Less defined furrow-and-ridge } \\
\text { topography }\end{array}$ \\
\hline Rock Glacier Body & $\begin{array}{l}\text { Swollen body } \\
\text { Surface ice exposures } 5\end{array}$ & $\begin{array}{l}\text { Flattened body } \\
\text { Surface collapse features (Barsch } \\
\text { and King, } 1975 \text { as cited in Janke et al. } \\
\text { [ref. 6]) }\end{array}$ \\
\hline Front Slope & $\begin{array}{l}\text { Steep }\left(\sim>30-35^{\circ}\right)^{4} \\
\text { Abrupt transition (i.e. sharp-crested) } \\
\text { to the upper surface } \\
\text { Light-coloured (little clast } \\
\text { weathering) frontal zone and a } \\
\text { darker varnished upper surface }{ }^{8}\end{array}$ & $\begin{array}{l}\text { Gently sloping }\left(\sim<30^{\circ}\right)^{4} \\
\text { Gentle transition (i.e. round crested) } \\
\text { to the upper surface }\end{array}$ \\
\hline
\end{tabular}




\begin{tabular}{|c|c|c|c|}
\hline & E - Himalaya & C - Himalaya & W - Himalaya \\
\hline Rock glacier proportion & $30 \%$ & $30 \%$ & $40 \%$ \\
\hline Proportional area $\geq 3225 \mathrm{~m}$ a.s.l & $26 \%$ & $37 \%$ & $37 \%$ \\
\hline Density $\left(n \mathrm{~km}^{-2}\right)^{*}$ & 0.08 & 0.08 & 0.06 \\
\hline Specific area $\left(\right.$ ha km$\left.{ }^{-2}\right) \dagger$ & 0.59 & 1.60 & 0.82 \\
\hline
\end{tabular}

*Density $\left(n \mathrm{~km}^{-2}\right)$ was calculated by considering the regional area $\geq 3,225 \mathrm{~m}$ a.s.l. (MEF of lowest observed landform). 


\begin{tabular}{lcccc}
\hline \multirow{2}{*}{ Activity } & \multirow{2}{*}{ Aspect Quadrant } & \multicolumn{3}{c}{ Region } \\
\cline { 3 - 5 } & & E - Himalaya & C - Himalaya & W - Himalaya \\
\hline \multirow{2}{*}{ Intact } & North (NW, N, NE) & $46 \%$ & $40 \%$ & $57 \%$ \\
\multirow{2}{*}{ Relict } & South (SW, S, SE) & $24 \%$ & $32 \%$ & $20 \%$ \\
& North (NW, N, NE) & $62 \%$ & $58 \%$ & $57 \%$ \\
& South (SW, S, SE) & $13 \%$ & $19 \%$ & $18 \%$ \\
\hline
\end{tabular}

817

818

819

820

821

822

823

824

825

826

827

828

829

830

831

832

833

834

835

836

837

838

839

840

841

842

843

844

845

846

847

848

849

850

851

852

853

854

855

856

857

858

859

860

861

862

863 


\begin{tabular}{|c|c|c|c|c|c|c|}
\hline \multirow[b]{2}{*}{ Region } & \multirow{2}{*}{\multicolumn{2}{|c|}{$\begin{array}{l}\text { Ice content by } \\
\text { volume }\end{array}$}} & \multicolumn{2}{|c|}{ Sample RGs } & \multicolumn{2}{|c|}{ Upscaled RGs } \\
\hline & & & \multirow{2}{*}{$\begin{array}{c}\begin{array}{c}\text { Ice volume } \\
\mathbf{( k m}^{\mathbf{3}} \mathbf{)}\end{array} \\
0.22\end{array}$} & \multirow{2}{*}{$\begin{array}{c}\begin{array}{c}\text { WVEQ } \\
\left(\mathbf{k m}^{\mathbf{3}}\right)\end{array} \\
0.20\end{array}$} & \multirow{2}{*}{$\begin{array}{c}\begin{array}{c}\text { Ice volume } \\
\mathbf{( k m}^{\mathbf{3}} \mathbf{)}\end{array} \\
4.50\end{array}$} & \multirow{2}{*}{$\begin{array}{c}\begin{array}{c}\text { WVEQ } \\
\left(\mathbf{k m}^{\mathbf{3}}\right)\end{array} \\
4.05\end{array}$} \\
\hline \multirow{3}{*}{ E - Himalaya } & Lower & $40 \%$ & & & & \\
\hline & Average & $50 \%$ & 0.28 & 0.25 & 5.62 & 5.06 \\
\hline & Upper & $60 \%$ & 0.34 & 0.30 & 6.74 & 6.07 \\
\hline \multirow{3}{*}{ C - Himalaya } & Lower & $40 \%$ & 3.73 & 3.36 & 28.27 & 25.44 \\
\hline & Average & $50 \%$ & 4.67 & 4.20 & 35.33 & 31.80 \\
\hline & Upper & $60 \%$ & 5.60 & 5.04 & 42.40 & 38.16 \\
\hline \multirow{3}{*}{ W - Himalaya } & Lower & $40 \%$ & 0.66 & 0.59 & 13.28 & 11.95 \\
\hline & Average & $50 \%$ & 0.82 & 0.74 & 16.60 & 14.94 \\
\hline & Upper & $60 \%$ & 0.99 & 0.89 & 19.92 & 17.93 \\
\hline \multirow{3}{*}{ Total } & Lower & $40 \%$ & 4.62 & 4.15 & 46.04 & 41.44 \\
\hline & Average & $50 \%$ & 5.77 & 5.19 & $\mathbf{5 7 . 5 5}$ & $\mathbf{5 1 . 8 0}$ \\
\hline & Upper & $60 \%$ & 6.92 & 6.23 & 69.07 & 62.16 \\
\hline
\end{tabular}

864

865

866

867

868

869

870

871

872

873

874

875

876

877

878

879

880

881

882

883

884

885

886

887

888

889

890

891

892

893

894

895

896

897

898

899 


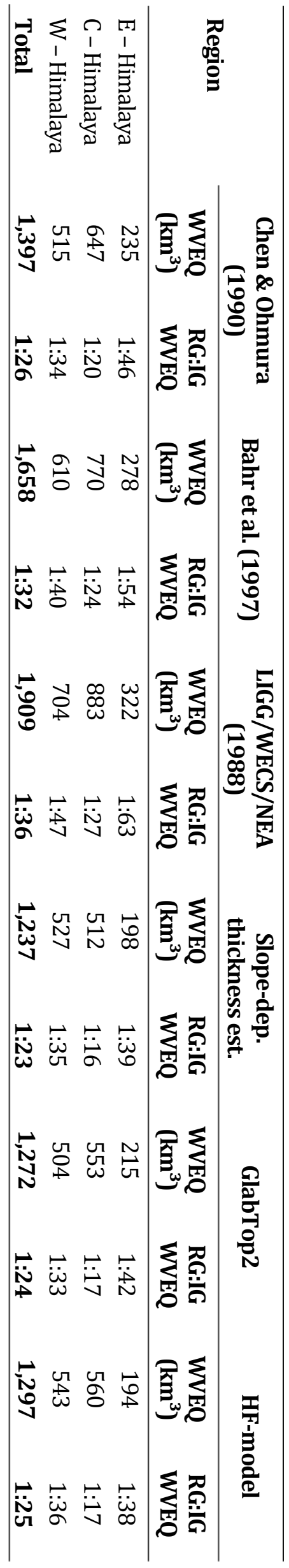




\begin{tabular}{|c|c|}
\hline Attribute & Attribute Explanation \\
\hline Name & Region_Feature No._MM/DD/YYYY* (e.g., WH_1_10/07/2013) \\
\hline Region & {$[\mathrm{EH}]$ East Himalaya, $[\mathrm{CH}]$ Central Himalaya, $[\mathrm{WH}]$ West Himalaya } \\
\hline DMSLon & Longitudinal coordinate of polygon centroid (DDD ${ }^{\circ}$ MM'SS.sss $[\mathrm{N} \mid \mathrm{S}]$ ) \\
\hline DMSLat & Latitudinal coordinate of polygon centroid (DDD ${ }^{\circ}$ MM'SS.sss [W|E]) \\
\hline MEF (m a.s.l.) & Minimum elevation at the front \\
\hline MaxE (m a.s.l.) & Maximum elevation of the feature \\
\hline Elevation (m a.s.l.) & Range | Mean \\
\hline Area $\left(\mathrm{km}^{2}\right)$ & / \\
\hline Mean Aspect $\left({ }^{\circ}\right)$ & $0-359$ \\
\hline Aspect Class & N, NE, E, SE, S, SW, W, NW (e.g., $90^{\circ}=\mathrm{E}, 180^{\circ}=\mathrm{S}$ ) \\
\hline Max Length (m) & / \\
\hline Mean Width (m) & / \\
\hline L:W Ratio & Length: width ratio \\
\hline Geometry Type & Tongue-shaped, Lobate-shaped \\
\hline Dynamic Type & Active, Inactive, Relict \\
\hline WVEQ $\left(\mathrm{km}^{3}\right)$ & $40 \%|50 \%| 60 \%$ \\
\hline Index Code & See Supplementary Table 7 \\
\hline Certainty Index & Medium_Certainty, High_Certainty, Virtual_Certainty \\
\hline
\end{tabular}

955

956

957

958

959

960

961

962

963

964

965

966

967

968

969

970

971

972

973

974

975

976

977

978

979

980

981

982

983

984

985

986 


\begin{tabular}{lccc}
\hline \multirow{2}{*}{ Parameter } & \multicolumn{3}{c}{ Parameter Options (Index Code) } \\
\cline { 2 - 4 } & 1 Point & 2 Points & 3 Points \\
\hline External Boundary & Unclear (OU) & Vague (OV) & Clear (OC) \\
Snow Coverage & Snow (SS) & Partial (SP) & None (SN) \\
Longitudinal Flow Structure & None (LN) & Vague (LV) & Clear (LC) \\
Transverse Flow Structure & None (TN) & Vague (TV) & Clear (TC) \\
Front Slope & Unclear (FU) & Gentle (FG) & Steep (FS) \\
Certainty Index Score & Medium Certainty & High Certainty & Virtual Certainty \\
& (MC) & (HC) & (VC) \\
& $\leq 5$ & 6 to 10 & $\geq 11$ \\
\hline
\end{tabular}




\section{Supplementary references}

10311 Frey, H. et al. Estimating the volume of glaciers in the Himalayan-Karakoram region using 1032 different methods. The Cryosphere 8, 2313-2333 (2014).

10332 Jones, D. B. et al. The distribution and hydrological significance of rock glaciers in the Nepalese 1034 Himalaya. Global and Planetary Change 160, 123-142 (2018).

10353 Kääb, A. \& Weber, M. Development of transverse ridges on rock glaciers: Field measurements and laboratory experiments. Permafrost and Periglacial Processes 15, 379-391 (2004). 4 Baroni, C., Carton, A. \& Seppi, R. Distribution and behaviour of rock glaciers in the Adamello-

5 Potter, J., N. et al. Galena Creek rock glacier revisited - new observations on an old controversy. Geografiska Annaler: Series A, Physical Geography 80, 251-265 (1998).

6 Janke, J. R., Regmi, N. R., Giardino, J. R. \& Vitek, J. D. in Treatise on Geomorphology Vol. 8, Glacial and Periglacial Geomorphology (eds J. Shroder, R. Giardino, \& J. Harbor) 238-273 (Academic Press, 2013).

7 Wahrhaftig, C. \& Cox, A. Rock glaciers in the Alaska range. Geological Society of America Bulletin

8 Bishop, M. P. et al. in Global Land Ice Measurements from Space (eds S. Jeffrey Kargel et al.) 509548 (Springer Berlin Heidelberg, 2014). 